\title{
The Impact of International Financial Reporting Standards (IFRS) Adoption on the Accounting Quality of Listed Companies in Kenya
}

\author{
Erick Rading Outa CPA(K) (Corresponding Author)) \\ Graduate School of Business Leadership ,University of South Africa \\ P.O. Box 18232, Code 00100 \\ Nairobi-Kenya \\ Cell 254 713608452, Email: ericouta2002@yahoo.co.uk
}

Received: July 14, 2011 Accepted: September 29, $2011 \quad$ DOI: 10.5296/ijafr.v1i1.1096

\begin{abstract}
This study seeks to establish if the adoption of International Financial Reporting Standards (IFRS) in Kenya has been associated with higher accounting quality for listed companies. The International Accounting Standards Board (IASB), in its objectives and preamble, supposes that the beneficial effects from IFRS adoption include transparency, accounting quality and reduced cost of capital. Based on these assumptions, this study applied accounting quality measures; earnings management, timely loss recognition and value relevance to find out whether the adoption of IFRS has led to improvements in accounting quality in companies listed in Kenya. The methodology is based on prior literature definition of metrics of accounting quality mainly earnings management, timely loss recognition and value relevance. The study differs from the previous ones by overcoming difficulties in controlling for confounding factors faced in previous studies which could have led to less reliable results. Three out of the eight metrics indicated that quality had marginally improved while five indicated that it had marginally declined. These mixed outcomes are very much in line with findings in other studies and the study contributes to the debate by explaining why accounting quality outcomes are still not consistent with IFRS promises in spite of improved test conditions.
\end{abstract}

Keywords: IFRS; IAS; accounting quality; earnings management; timely loss recognition 


\section{Introduction}

This study sets out to examine whether the adoption of International Financial Reporting Standards (IFRS) ${ }^{\mathrm{i}}$ by listed companies in Kenya has improved the quality of financial reporting. Kenya adopted IFRS, and then referred to as International Accounting Standards (IAS), in 1999 through a resolution by the Council of the Institute of Certified Public Accountants of Kenya (ICPAK), the legally mandated accounting institute in Kenya. The study compares changes in the quality of accounting between the pre-adoption period from 1995 to 1999 and the post adoption period from 2000 to 2004. The study specifically tests whether there is less earnings management, more timely loss recognition and higher value relevance in the adoption period as opposed to the pre adoption period. It also takes a global perspective to the IFRS question in relation to quality. The outcomes of the study show mixed results with some of the metrics indicating a marginal increase in accounting quality and others showing a decrease in the quality of accounting.

Since their inception, International Accounting Standards have been produced by two bodies. The first, the International Accounting Standards Committee (IASC) came up with 41 accounting standards between 1973 and 2000. The IASC was replaced by the International Accounting Standards Board (IASB) in the year 2000. The new Board embarked on a review processes aimed at refining the standards. The result was a reduction in the number of standards from 41 in the year 2000 to 28 by the year 2008. By 2011, 13 standards had been issued by the board as International Financial Reporting standards (IFRS). According to IAS Plus (2010), IFRS refers to the entire body of IASB pronouncements including standards and interpretations approved by IASB, IASC and their interpretations produced by the Accounting Standards Interpretations Committee (IASIC). IFRS orIAS have also been described as a set of standards stating how particular types of transactions and other events should be reflected in financial statements, issued by IASC and IASB (ACCA 2008:41). The primary objective of the accounting standards is to enable corporations to provide investors and creditors with relevant, reliable and timely information which is in line with the IASB's accounting framework for the preparation and presentation of Financial Statements. Such information, it is argued, contributes towards the achievement of orderly capital markets around the world Imhoff (2003:117). The concept of accounting quality is based on the IASB framework where relevance, reliability, understandability and comparability (IFRS 2006:38) are key components and therefore, assumed that financial statement with the four qualitative characteristics have better quality. Chen et al. (2010:222) has simply described accounting quality as the extent to which the financial statement information reflects the underlying economic situation. In simple terms, this study seeks to establish if the adoption of IFRS has improved qualitative characteristics of the financial reporting in Kenya, where such improvement would be regarded as improvement in quality.

Controversies always existed over the suitability of applying IFRS in developing countries with researchers such as Singh and Newberry (2008:485) as well as Chen et al. (2010:221) arguing that there exist two schools of thought in this area. The first supports a single set of global standards as being suitable for application. The second opposes the use of IFRS in developing countries by arguing that the characteristics of local business environments and 


\section{Mll Macrothink}

International Journal of Accounting and Financial Reporting ISSN 2162-3082 2011, Vol. 1, No. 1

institutional frameworks determine the form and contents of accounting standards. Kenya and many developing countries are characterized by weak institutions and volatile economic and political environments which are not very conducive to assimilation of IFRS .In spite of the arguments, many countries and companies have adopted IFRS and the need to evaluate their impact has been overwhelming. Barth et al. (2007:2) indicate that accounting amounts results from interaction of features of the financial reporting system which include accounting standards, their interpretations, enforcement, and litigation and this obviously leads to obtaining different results from application of the same standards. Ball et al. (2003) by extension argue that high quality standards like IFRS may also lead to low quality accounting information depending on the incentives of the preparers. It is these contradictions that led Ball et al. (2003) and others to conclude that poor preparer incentives, underlying economic and political factors influence manager and auditors incentives as opposed to accounting standards. Many factors have also been cited as impacting financial reporting practices such as effective enforcement of standards and strong corporate governance.

Critiques of IFRS such as Barth et al. (2007:7) and Bartov et al. (2005:114) argue that there is no conclusive evidence that standards have contributed to improvements in accounting quality. Although, the objective of this study is similar to those of previous studies, it departs from these studies in several ways. It addresses the peculiarities discussed above with a view to coming up with a more valid and reliable outcome on the extent of the impact of IFRS on accounting quality. This study has achieved this by comparing accounting quality in the pre and post adoption periods where both eras having a clear dividing line. Each company in the study acts as its own control by matching data in the pre and post thus ensuring same conditions for measurement. The confounding effects of the macro-economic and political environment are completely eradicated since all the companies are subject to the same economic environment and governmental control. This methodology differs from prior studies as applied by Barth et al. (2007) in their 21 country study around the globe with too many diversified environmental and managerial incentives that cannot be effectively eliminated. This study also improves on the attempts by Chen et al. (2010) in their $15 \mathrm{EU}$ country study. According to Soderstrom and Sun (2007:677), the EU had diverse legal, political and economic systems leading to a vast variety of accounting and Financial reporting systems and the believe by Chen et al. (2010) that their study controlled for all this diversity is too soon with very different economic platforms in each country, given that EU adoption became mandatory from 2005. The study by Elbannan (2011) in a study of code law country, Egypt covered a very short period in 1997 and 2006. Paananen has carried near similar studies in Germany and Sweden and the differences being companies quoted in several stock exchanges in advanced economies where managerial and economic incentives are quite different. This Kenya study has addressed these challenges including extending the data over 10 years period (five before and five after) in a single exchange setting and having officially adopted IFRS earlier than any other known country. The Kenya study is therefore close to an excellent experimental set up, though suffers from a small sample due to the size of the stock exchange.

With these experimental conditions under control, one would expect absolute findings; 


\section{Mll Macrothink}

International Journal of Accounting and Financial Reporting ISSN 2162-3082 2011, Vol. 1, No. 1

however prediction that IFRS will improve quality may still not come true. Barth et al. (2007:3) explains the reasons could be due to IFRS being of lower quality than local standards, principle based standards could be interpreted either way or some features of financial reporting system other than standards could eliminate improvements in quality.

Using 54 companies listed in Nairobi Stock Exchange resulting in 320 firm year observations, this study found mixed results that suggest neither increase nor decrease in accounting quality for reasons that are well linked to existing literature. When IFRS is adopted in a common law country where IASB framework is nearly similar to the domestic frameworks and where enforcements and institutional frameworks are not strong, it is possible that major changes may not be noticed in accounting quality.

The study has several implications. The findings should enable regulators and other key player to gauge the effectiveness of the financial reporting system in place such as training and development for practitioners and new members, due diligence for Accounting standards and the overall institutional and professional organization conducive for effective standards application. The other implication is that the study is part of a vetting process for IFRS. Should the results indicate that there is positive impact, then that will go towards confirming IFRS as a quality standard. Should the results indicate that there are no quality improvements, and then the findings would highlight the missing link why IFRS is not delivering the promised benefits?

The study will contribute in three main areas. First, it will provide additional perspectives to IFRS literature from a developing economy regarding financial statement and market impact of IFRS adoption since empirical evidence has not been assessed before in an area where market structures and managerial behaviors are distinct from developed world where most studies are based. Second, this study is the first to extend the earnings quality literature and value relevance using Kenyan sample. Finally, the study will interrogate the institutional structures of accounting profession from time immemorial to determine how quality has evolved in this common law country and thus strengthen literature on the role of professional and institutional structures in accounting quality issues.

The reminder of the paper is organized as follows. Section 2 discusses some conceptual underpinnings from a global perspective as they apply to this study, section 3 discusses the Kenya business context and accounting profession in Kenya, section 4 discusses methodology, section 5 is the data while section 6 discusses the findings and section 7 is the conclusion. Table 1-7 are provided to give additional evidence of the findings.

\section{Conceptual Underpinnings and Brief Literature Review}

According to Barth et al. (2007:2), IASB's goal of developing an internationally acceptable set of high quality financial reporting standards also meant allowable accounting alternative and accounting measurements that better reflect economic position and performance. Ashbaugh and Pincus (2001:422) argue that limiting alternatives can increase accounting quality because doing so limits managements' opportunistic discretion in determining accounting amounts. Therefore, accounting amounts that reflect a firm's underlying 
economics can increase accounting quality because investors will have access to better information for their decision making. Other accounting literature in this area also argues that more rigorous enforcement of adoption can also lead to better accounting quality. On this basis, this study hypothesizes that accounting amounts reported on IFRS basis in Kenya are of higher quality than those of the domestic standards known as Kenya Accounting Standards (KAS).

The problem with this hypothesis is that IFRS could be of lower quality thus, limiting managerial discretion relating to measurements that are more reflective of the firm's economic position and performance. Closely associated with this is the question of flexibility in principle based standards which could lead to better opportunities for a firm to manage its earnings thus, decreasing accounting quality (Barth et al. 2007:6; Chen 2010:226). Another argument associated with this hypothesis has been the so called label and serious adopters' by Daske et al. (2007:16) debate whereby, some firms, referred to as label adopters, claim that they have adopted IFRS while the degree of adoption could be nil or low and sometimes enforcement of such standards would be nonexistent.

In comparing domestic standards to IFRS, some studies have shown that there are no significant differences in accounting results with the implication that the adoption of IFRS does not result in better accounting quality. Studies in Germany by Tendeloo and Vanstraelen (2005:1) and Hung and Subramanyam (2007:36) did find similarities in earnings management and value relevance in comparing results of the national and international standards. Paananen (2008:17) reports no quality increases in the Swedish case and Elbannan (2011:240) reports mixed findings in Egypt. On this basis, it is also hypothesized that the adoption of IFRS in Kenya as compared to KAS given mandatory adoption and KAS framework being similar to IASB's may yield mixed results.

Accounting literature has operationalized accounting quality on the basis of earnings management, timely loss recognition and value relevance metrics. The arguments follow then that firms with higher quality earnings exhibit less earnings managements, more timely loss recognition and higher value relevance and this study hypothesizes the same for Kenya.

\section{Kenya's Economic and Business Context}

\subsection{Kenya's Business Compliance Index}

In 2009, the Kenya Business Indicator Index (KBII) gave the country a score of 6.48 out of 12 and ranked it at 71 out of 100 countries (Standards Forum 2009:4). Similarly, the country was ranked 72 out of 100 in the 2009 E-standards forum index. The key objective of the E-standards forum and the KBII indices is to monitor a country's economic, financial and political performance so as to provide investors, policy makers, donors and other stakeholders with the country risk profile and conformity with best practices. From these two indices, it is clear that Kenya's compliance is quite low.

These indices send mixed signals about Kenya's business climate as well as the fact that in 


\section{Ml Macrothink}

International Journal of Accounting and Financial Reporting ISSN 2162-3082 2011, Vol. 1, No. 1

spite of the challenges of implementing the standards, many things are on track. The low human capital index is also interesting as Kenya suffers an acute shortage of highly skilled manpower in key professional areas such as accounting and finance which therefore, affects the quality of activities in the economy. The shortage of manpower is collaborated by the UNDP Human Development Index (HDI) for 2010 of 0.470 ranks Kenya as number 128 out of 177 (UNDP 2010:14) countries. Furthermore, the training of accountants in universities in Kenya has not met the industries demands and ICPAK estimates that although 30,000 accountants are required in Kenya, less than 5000 are actively involved with the institute. Manpower at the faculty level is also scarce and unofficial statistics indicate there are less than five Doctorates in Accountancy in the entire country with three of them past retirement.

\subsection{Comparative Analysis of Accounting Development in Kenya over the Years}

There is very little information on the background of accountancy in Kenya, an indication that a clear track which could be a pointer to the strengths of the profession over the years has not been kept. In a recent publication celebrating ICPAK's 30 year anniversary (Accountant 2008:33 May), the writer described the pre-independence days of the accountancy profession as "an expatriate affair with no Kenyans, neither Africans nor Asians." This was a communication of racism which by extension implied that the quality of accounting during the pre independence period and early post independence was biased and therefore, could not have been quality driven. The early post independence period extends to 1977 when the Institute of Certified Public Accountants was promulgated. This period was characterized by inadequate institutions to train accountants locally and bridge the gap of diversity. Prior to the commencement of ICPAK, most accountants were members of institutes in the UK and India and, amazingly, there was little government involvement in the profession. Through to the sixties and seventies, accountants in Kenya mainly sat for the Chartered Accountants exam in the UK and it is difficult to understand how such external exams were tailored to the Kenyan environment in areas such as taxation, finance, and even financial reporting. Among the earliest accounting exam in Kenya was the Institute of Municipal Treasurers and Accountants (IMTA) which was modified to suit Kenya's situation. The first known accounting association in Kenya was the Association of Accountants in East Africa (AAEA) from which accountants could articulate their professional challenges, foremost being concerns about the quality training. While these efforts were commendable, the association came up with accounting exams but not formal qualifications. Furthermore, in these early years, accountancy was governed by the Accountants Designation Act (Cap 524) and the Companies Act (cap 486). Ironically, these acts provided for the appointment and recognition of accountants only if they were members of English, Scottish or Irish designations.

The vacuum days saw all kinds of experiences with organizations and businesses having several sets of financial reports; one for tax, one for bank financing and one for the owner where real reporting was actually reflected (The Accountant 2008:34 May). This practice persisted for many years, even up to recent times, even though on a declining basis.

\subsection{Institutional Framework of Accounting in Kenya}




\section{Mll Macrothink}

International Journal of Accounting and Financial Reporting ISSN 2162-3082

The institutional framework of accounting in Kenya refers to the way the accounting profession is organized in the country. It focuses on five areas namely; the legal framework( Company's Act Cap 486), the Accountants Act(Incorporates the Institute of Certified Public Accountants of Kenya (ICPAK, Kenya Accountants and Secretaries National Examination Board (KASNEB) ) and the regulators ( Capital Markets Authority, The Central Bank, Insurance Regulatory Authority and the Stock Exchange.

Although ICPAK was established over 30 years ago (1977), as at Nov 2009, 18,000 people had passed KASNEB administered Accountancy (CPA) examination but only 6,000 had become ICPAK members (World Bank 2010:9). This implies that accountants who have passed exams, but have not registered with ICPAK, are not receiving appropriate Continuous Professional Education (CPE) and the guidance required to conduct the functions of accounting thereby, diluting the quality of accounting. IFRS is a critical component of the accounting quality process as it forms the basis of professional practice in any country. In spite of this, slightly over ten years since IFRS was adopted in Kenya, the Accountants Act has not been explicit on ICPAK issuing IFRS. This has led to a situation where there is no legal basis upon which reinforcement can be effected by ICPAK.

The other Act relevant to accounting in Kenya is the Companies Act known as cap 486 which was modeled alongside the UK Companies Act of 1948. This Act requires all limited liability companies to keep proper books of accounts from which to prepare accounts that give a in the UK, the act has been amended through the Companies Act of 1985 and 1989 by incorporating the requirements of the UK accounting standards. In fact, the Kenya Companies Act is not harmonized with the Accountants Act (1977 and 1998). According to UNCTAD (2005) the requirements of the Act do not recognize the institute's authority to oversee and prescribe the financial reporting framework. The Act has also been criticized for not defining what true and fair view is. Moreover, an important requirement such as cash flow provided for in the Standards is not prescribed in the Act. These inconsistencies make it difficult to enforce IFRS.

\section{Research Design and Method}

\subsection{Introduction}

Barth et al. (2007) like Christensen et al. (2008) and others argue that the metrics of accounting quality reflects the effects of the financial reporting system as well those attributable to financial reporting such as the economic environment and incentives associated with the adoption of standards. As stated in the introduction, this study intended to overcome these challenges and mitigate the confounding factors to ensure valid and reliable outcomes. In the case of Barth et al. (2007), this was a major problem because the research spread over 21 countries with different economic systems and incentives while in the Christensen research, the problems were overcome by focusing on one country, Germany, mainly because within a single a country, the underlying economic environment is the same for all the firms. This research took a similar approach to that of Christensen et al.(2008) and Barth et al.(2007) by making a comparison of the impact of adoption on accounting quality in firms during the pre adoption period and the post adoption period. Chen et al (2010) concur 


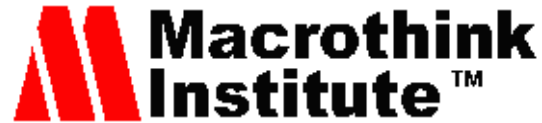

International Journal of Accounting and Financial Reporting ISSN 2162-3082

that matching firms in the pre and post adoption periods within a similar economic zone is the best control that ensures that only one variable (IFRS) is being investigated. Since the study focused on listed companies in Kenya, where compliance is mandatory, no other effects needed to be adjusted to ensure that the results were acceptable.

As is the case in prior research, Barth et al. (2007) argued that there is no definitive way to determine the degree to which these research design features mitigate the effects of the economic environment and incentives on the metrics. It is therefore, expected that the choice of a single country, Kenya, and not a region like East Africa or Africa, together with the matching of data in the pre and post periods will control for effects such as enforcement and litigation as well address the issues of incentives. In line with Paananen and Lin (2007) some institutional factors held constant including stock listing requirements, accounting disclosure requirements, market microstructures and regulatory environments thus, strengthening the reliability of the findings.

In constructing a matched sample consistent with Lang et al. (2003), the year of adoption and industry was identified and a check made to ensure that the audited financial report clearly state the accounting standard used. Ultimately, the samples were divided into Pre and Post adoption as well IFRS and Non IFRS (NIFRS) firms.

\subsection{Population Size}

In this study, the population refers to all companies listed in the Nairobi Stock Exchange (NSE) between 1995 and 2004. It is notable that the period between 1995 to 2004 maybe outdated but given that this is a baseline study, no such study has ever taken place and the need to bring these studies to third world renders the study appropriate. The characteristics of the sample firms during each of the two periods are described in tables 2 and 3.

\subsection{Research Method and Procedures}

Quantitative methods were used to collect secondary data related to financial reporting including revenues, income, balance sheet and cash flow data. Data collected was processed on STATA and the output shown from table 1.The metrics applied in the study were Earnings management, Timely loss recognition and value relevance as discussed below.

\subsubsection{Earnings Management}

Prior literature distinguishes between two kinds of earnings management known as earnings smoothing and managing towards small positive earnings. According to Barth et al. (2007:12), earnings smoothing is measured by three constructs: variability of changes in earnings, variability of changes in earnings relative to the variability of changes in cash flow and negative correlation between accruals and cash flows. Lang et al. (2003) and Leuz et al. (2003) also postulate that high variability of earnings is consistent with less smoothing of earnings. The other construct of earnings management is the managing towards small positive earnings and this is done because management prefers to report small positive net income rather than negative net income.

\subsubsection{Variability in Earnings ( Equation 1)}




\section{Macrothink}

International Journal of Accounting and Financial Reporting

ISSN 2162-3082 2011, Vol. 1, No. 1

A small variance of the change in net income is interpreted as evidence of earnings smoothing and could be affected by other factors unrelated to earnings smoothing. To mitigate against these factors, the measure of earnings variability is the variance of the residuals from the regression of change in net income on control variables identified in prior research.

In line with Barth et al. (2007:22), residuals from regression equations are:

$$
\begin{aligned}
& \Delta \text { NI }_{i t}=\alpha_{0}+\alpha_{1} \text { SIZE }_{i t}+\alpha_{2} \text { GROWTH }_{i t}+\alpha_{3} \text { EISSUE }_{i t}+\alpha_{4} \mathrm{LEV}_{\mathrm{it}} \\
& +\alpha_{5} \text { DISSUE }_{i t}+\alpha_{6} \text { TURN }_{i t} \\
& +\alpha_{7} \text { CF }_{i t}+\alpha_{8} \mathrm{AUD}_{\mathrm{it}}+\alpha_{9} \mathrm{NUMEX}_{\mathrm{it}} \\
& +\alpha_{10} \mathrm{XLIST}_{\mathrm{it}}+\alpha_{11} \mathrm{CLOSE}_{\mathrm{it}} \sum_{k=0}^{6} \propto_{\mathrm{K}+11}+\varepsilon_{\text {iiEquation } 1}
\end{aligned}
$$

Where:

$\Delta \mathrm{NI}_{i t}$-Change in annual earnings (based on end of year total assets) for firm I year $\mathrm{t}$.

SIZE-is the natural logarithm of market value of equity in millions of shillings as of year end GROWTH-Annual \% of change in sales

EISSUE-annual \% change in common stock

LEV-end year total liabilities divided by end year book value of equity

DISSUE-annual \% change in total liabilities

TURN-Sales divided by end of year total assets

CF-Annual net cash flow from operating activities scaled by end of year total assets

AUD-an indicator that equals 1 if the auditor is one of the large international accounting firms

NUMEX-Number of exchange listings (In our case, it is 1)

XLIST-an indicator that equals 1 if the firm is listed on any US stock exchange and world scope (Will not be applicable in our case)

CLOSE-\% of closely held shares (Not applicable in our case)

In this equation, a summary is made of all the NI in the pre and post adoption period and regressed against the controls 


\section{Macrothink}

International Journal of Accounting and Financial Reporting

ISSN 2162-3082 2011, Vol. 1, No. 1

\subsubsection{Variability of $\Delta N I \quad$ over $\triangle C F$ (Equation 2)}

Generally, firms with more volatile cash flows typically have volatile net income. The principle behind this measure is that when firms use accruals to manage earnings, then variation in income should be lower than that of operating cash flows.

$$
\begin{aligned}
& \Delta C F_{i t}=\alpha_{0}+\alpha_{1} \text { SIZE }_{i t}+\alpha_{2} \text { GROWTH }_{i t}+\alpha_{3} \mathrm{EISSUE}_{i t}+\alpha_{4}+\mathrm{LEV}_{\mathrm{it}} \\
& +\alpha_{5} \text { DISSUE }_{i t}+\alpha_{6} \text { TURN }_{i t}+\alpha_{7} \mathrm{CF}_{i t}+\alpha_{8} \mathrm{AUD}_{\mathrm{it}}+\alpha_{9} \mathrm{NUMEX}_{\mathrm{it}} \\
& +\alpha_{10} \mathrm{XLIST}_{\mathrm{it}}+\alpha_{11} \mathrm{CLOSE}_{\mathrm{it}} \sum_{k=0}^{6} \alpha_{\mathrm{K}+11}+\varepsilon_{\mathrm{ii}}
\end{aligned}
$$

Where:

$\Delta \mathrm{CF}_{i t}$-change in annual net cash flow from operations(based on end of year total assets) for firm i year $\mathrm{t}$.

Like $\Delta \mathrm{N}, \Delta \mathrm{CF}$ can also be affected by other factors outside IFRS hence the need for $\Delta \mathrm{CF}$ as dependent variable.

\subsubsection{Correlation of Accruals to Cash flow (Equation 3 and 4)}

Studies by Lang M., Raedy J and Yetman M (2003:385) further concluded that firms with less earnings smoothing exhibit a more negative correlation between accruals and cash flows because accruals reverse over time and are generally negatively correlated to cash flows. In these metrics, Spearman's correlation between accruals and cash flows are applied.

$$
\begin{aligned}
& C F_{i t}=\alpha_{0}+\alpha_{1} \text { SIZE }_{i t}+\alpha_{2} \text { GROWTH }_{i t}+\alpha_{3} \mathrm{EISSUE}_{i t}+\alpha_{4}+\mathrm{LEV}_{\mathrm{it}} \\
& +\alpha_{5} \text { DISSUE } E_{i t}+\alpha_{6} \operatorname{TURN}_{i t} \alpha_{7} \mathrm{AUD}_{\mathrm{it}}+\alpha_{8} \mathrm{NUMEX}_{\mathrm{it}} \\
& +\alpha_{9} \mathrm{XLIST}_{\mathrm{it}}+{ }_{10} \mathrm{CLOSE}_{\mathrm{it}+} \varepsilon_{\mathrm{ii}} \\
& A C C_{i t}=\alpha_{0}+\alpha_{1} \text { SIZE }_{i t}+\alpha_{2} \text { GROWTH }_{i t}+\alpha_{3} \text { EISSUE }_{i t}+\alpha_{4}+\mathrm{LEV}_{\mathrm{it}} \\
& +a_{5} \operatorname{DISSUE}_{i t}+\alpha_{6} \operatorname{TURN}_{i t}+{ }^{\alpha} \mathrm{AUD}_{\mathrm{it}}+\alpha_{8} \mathrm{NUMEX}_{\mathrm{it}} \\
& +\alpha_{9} \mathrm{XLIST}_{\mathrm{it}}+\alpha_{10} \mathrm{CLOSE}_{\mathrm{it}}+\varepsilon_{\mathrm{ii}}
\end{aligned}
$$




\section{$\triangle$ Macrothink}

International Journal of Accounting and Financial Reporting

ISSN 2162-3082

Where

$\mathrm{CF}_{i t}$-Annual net cash flow from operating activities scaled by end of year total assets for firm i year $\mathrm{t}$.

$\mathrm{ACC}_{i t}$-earnings less cash flow from operating activities (scaled by end of year total assets) for firm i year $\mathrm{t}$.

All the metrics in pre and post adoption period will be calculated separately and tested for statistical significance per Barth et al. (2007) by applying t-test based on the empirical distribution of the differences. Since this study is census, this test will not apply

\subsubsection{Earnings Management towards a Target (Small Positive Earnings)}

This is the second measure for earnings management. This study focused on managing towards small positive net income NI (SPOS). Other measures related to positive earnings target were based on studies by Leuz, Nanda and Wysocki (2003:519) in which evidence was adduced to the effect that a large frequency of small positive earnings is an indication of managing towards positive earnings. The conclusion from these studies was that firms applying IAS report small positive earnings with lower frequency.

\subsubsection{Small positive earnings -NI (SPOS) Equation 5 and 6)}

$$
\begin{aligned}
& \operatorname{IAS}(0,1)_{i t}=a_{0}+\alpha_{1} \operatorname{SPOS}_{i t}+\alpha_{2} \text { SIZE }_{i t}+\alpha_{3} \text { GROWTH }{ }_{i t}+\alpha_{4} \mathrm{EISSUE}_{i t}+\alpha_{5}+\mathrm{LEV}_{\mathrm{it}} \\
& +\alpha_{6} \operatorname{DISSUE}_{i t}+{ }^{\alpha_{7}} \operatorname{TURN}_{i t} \\
& +\alpha_{8} C F_{i t}+\alpha_{9} \mathrm{AUD}_{\mathrm{it}}+\alpha_{10} \mathrm{NUMEX} \text { it } \\
& +\alpha_{11} \mathrm{XLIST}_{\mathrm{it}}+\alpha_{12} \mathrm{CLOSE}_{\mathrm{it}}+\varepsilon_{\mathrm{ii}}
\end{aligned}
$$

Where:

IAS $(0,1)_{i t}$ is an indicator variable that equals one for IFRS firms and Zero for NIFRS and SPOS $_{i t}$ is an indicator variable that equals one if net income scaled by total assets is between 0 and 0.01 .

\section{Interpretation:}

1. A negative coefficient on SPOS indicates that NIAS firms manage earnings towards small positive amounts more frequently than do IAS firms.

$\operatorname{POST}(0,1)_{i t}=\alpha_{0}+{ }_{1}{ }_{1} \operatorname{SPOS}_{i t}+\alpha_{2}$ SIZE $_{i t}+\alpha_{3} G R O W T H_{i t}+\alpha_{4} \mathrm{EISSUE}_{i t}+\alpha_{5}+\mathrm{LEV}_{\mathrm{it}}$ 


\section{Ml Macrothink}

$$
\begin{gathered}
+\alpha_{6} \text { DISSUE }_{i t}+\alpha_{7} \text { TURN }_{i t} \\
+\alpha_{8} C_{i t}+\alpha_{9} \mathrm{AUD}_{\mathrm{it}}+\alpha_{10} \mathrm{NUMEX}_{\mathrm{it}} \\
+\alpha_{11} \mathrm{XLIST}_{\mathrm{it}}+\alpha_{12} \mathrm{CLOSE}_{\mathrm{it}} \sum_{k=0}^{6} \propto_{\mathrm{K}+12}+\varepsilon_{\mathrm{ii}}
\end{gathered}
$$

Where:

POST $(0,1)$ is an indicator variable that equals one for observations in the post-adoption period and zero otherwise. SPOS is an indicator variable that equals one for observations where net income scaled by total assets is between zero and .01. A negative coefficient on SPOS suggests that firms manage less towards a small positive target in the post adoption period.

\section{Interpretation:}

1. A negative coefficient on SPOS indicates that IAS firms manage earnings towards small positive amounts more frequently in the pre adoption period than they do in the post adoption period.

\subsubsection{Timely Loss Recognition}

As the name implies, timely loss recognition relate to an organization's ability to recognize losses as they occur by not engaging in activities that reschedule the losses to other periods. It is measured as coefficient on large negative net income (LNEG) in the regressions equation 7 and 8 .

Studies by Lang, Raedy and Yetman (2003) suggest that higher quality earnings report losses when they occur instead of being deferred to future periods. From Barth et al. (2007:26), the measure is based on the regression equation

\section{Large Negative Income (Equation 7 and 8)}

\section{Equation 7 (Pre adoption)}

$$
\begin{aligned}
& \operatorname{IAS}(0,1)_{i t}=a_{0}+\alpha_{1} L N E G_{i t}+\alpha_{2} \text { SIZE }+\alpha_{3} G R O W T H_{i t}+\alpha_{4} \mathrm{EISSUE}_{i t}+\alpha_{5}+\mathrm{LEV}_{\mathrm{it}} \\
& +\alpha_{6} D_{I S S U E}+{ }_{i t}{ }_{7} \operatorname{TURN}_{i t} \\
& +\alpha_{8} C F_{i t}+\alpha_{9} \mathrm{AUD}_{\mathrm{it}}+\alpha_{10} \mathrm{NUMEX}_{\mathrm{it}}
\end{aligned}
$$




$$
+{ }_{11} \mathrm{XLIST}_{\mathrm{it}}+{ }^{\alpha}{ }_{12} \mathrm{CLOSE}_{\mathrm{it}}+\varepsilon_{\mathrm{ii}}
$$

LNEG isan indicator variable that equals one for observations for which annual net income scaled by total assets is less -.20 and Zero otherwise. A positive coefficient on LNEG indicates that IAS firms recognize large losses more frequently than NIAS firms.

\section{Equation 8 (Post adoption)}

$$
\begin{aligned}
& \operatorname{POST}(0,1)_{i t}=a_{0}+{ }^{\alpha}{ }_{1} L_{N E G_{i t}}+{ }^{\alpha_{2}} \text { SIZE }+\alpha_{3} G R O W T H_{i t}+\alpha_{4} \mathrm{EISSUE}_{i t}+\alpha_{5}+\mathrm{LEV}_{\mathrm{it}} \\
& +\alpha_{6} \operatorname{DISSUE}_{i t}+{ }^{\alpha_{7}} \operatorname{TURN}_{i t} \\
& +\alpha_{8} C F_{i t}+\alpha_{9} \mathrm{AUD}_{\mathrm{it}}+\alpha_{10} \mathrm{NUMEX} \text { it } \\
& +\alpha_{11} \mathrm{XLIST}_{\mathrm{it}}+\alpha_{12} \operatorname{CLOSE}_{\mathrm{it}} \sum_{k=0}^{6} \alpha_{\mathrm{K}+12}+\varepsilon_{\mathrm{ii}}
\end{aligned}
$$

Where:

LNEG is an indicator variable that equals one for observations in which annual net income scaled by total assets is less than -0.20 and Zero otherwise. A positive coefficient on LNEG suggests that IFRS firms recognize large losses more frequently in the post adoption period than they do in the pre adoption period.

A positive coefficient on LNEG indicates that IAS firms recognize large losses more frequently in the post adoption period than they do in the pre adoption period.

There are other measures for timely loss recognition such as that suggested by Basu (1997).

\subsection{Value relevance}

Value Relevance according to Stergios et al. (2005:10) is the ability of the summary accounting measures to reflect the underlying economic value of the firm. These are measured through contemporaneous stock prices. In simple terms, value relevance tries to associate a firm's value as expressed in stock prices to the reported income statement and balance sheet. The arguments here are around the fact that IFRS/IAS possibly improves the book values (valuation measurements) at the expense of net income.

In line with Barth et al. (2007:27), it is proposed to regress stock price, $\mathrm{P}$, on industry fixed assets and the residuals from this regressions on equity book value per share (BVEPS) and net income per share NIPS.

\section{Price (Equation 9)}

$\mathbf{P}_{\mathrm{it}=} \beta_{0}+\beta_{1}$ BVEPS $_{i t}+\beta 2 N I P S_{i t}+\varepsilon_{\mathrm{ii}}$ 
Where

$\mathrm{P}_{\text {it }}$-Price as of 6 months after fiscal year end (Ensures accounting information is in public domain)

BVEPS-Book value of equity per share

NI/P-earnings per share divided by beginning of year prices

NIPS-Net income per share

The next value relevance equation is based on the explanatory power from regressions of net income per share on annual stock return. In the study by Ball et al. (2000), accounting quality differences will be most pronounced for "bad news"because when forms have good news, they have less incentive to manage earnings. To obtain good and bad news value relevance metrics regression of net income per share, NI/P on industry fixed assets.

The last value relevance metrics is the $\mathrm{R}^{2}$ from the regression equation below estimated for good news and bad news firms

\section{Good or Bad news Equation 10}

$[\mathrm{NI} / \mathrm{P}]^{*} \mathrm{it}=\beta_{0}+\beta_{1} R E T U R N_{i t}+\varepsilon_{\mathrm{ii}}$

Where

NI/P-earnings per share divided by beginning of year prices

RETURN-annual stock return from 9 months prior to 3 months after the firms fiscal year end These equations will be estimated separately for IFRS and NIFRS firms.

\section{Data}

The data included in the survey comprised of 320 observations of 32 firms between 1995 and 2004 (10 years) based on data available from the NSE. During the study period, none of the firms was listed in any other stock exchange. The data obtained was divided into five years before IFRS adoption (1995-1999) and five years after IFRS adoption (2000-2004). The raw data comprised of extract audited financial statements that indicated which accounting standards were applied. In this case, audits up to 31 December 1999 were based on Kenya Accounting Standards while those after 31 December 2000 were based on IFRS. Table 2 represents the industry

\section{INSERT TABLE 2 HERE}

breakdown of the firm year observations of 36 companies over a period of 10 years. The greatest representation was from manufacturing, industrial and allied companies which had a 


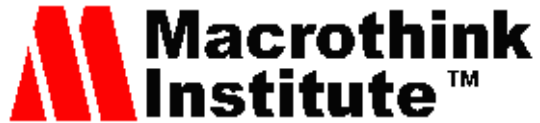

International Journal of Accounting and Financial Reporting ISSN 2162-3082 2011, Vol. 1, No. 1

total of 126 firm year observations, followed by financial services companies with 110 firm year observations, commercial services companies with 50 firm year observations and agricultural sector companies with 34 firm year observations. Table 3 supplements this data by indicating the number of firm year observation for each year.

To mitigate the effect of different firms in each period, on the regression estimations, the sample firms in one period were matched with the same firm in the next period. Consequently, the 320 firm year observations have equal number of IFRS and NIFRS firms as shown in table 2 .

Table 4 represents descriptive statistics for earnings smoothing, timely loss recognition and value relevance followed by control variables.

\section{INSERT TABLE 4 HERE}

These descriptive statistics do not control for other factors. As per prediction, there is an increase in variability from -0.019 in the pre adoption period to 0.010 in the post adoption period. This change suggests that there was higher variability after IFRS adoption thus, improved quality of accounting. Unlike earnings, the change in cash flow worsened from 0.005 to -0.010 contrary to prediction could be due to the performance in the economy. This is supported by table 7 which shows that NSE share index dipped between 1994 and 2003. During this time, the index worsened from 4559.40 in 1994 to 1362 in 2002.In the same period , market capitalization decreased from ksh 136 billion to an all time low of ksh 86 billion. Cash flow variable also decreased from 0.098 for reasons mentioned in the variability in cash flows which are economy related.

Table 4, also indicates that there are relatively low incidences of small positive earnings in the pre adoption period ( 0.081 compared 0.082$)$ even though the difference is quite small. Pre adoption period also appear to have low frequency of large negative income which suggest quality did not improve much given these measures are quite insignificant.

In addition to this, RETURN has also improved from 0.001 to 0.011 . While this contradicts the performance in the economy because share prices came down, it is possible there could have been other factors the study did not control for. Net Income Per share (NI/P) worsened from 0.126 to 0.060 and this is mainly due to the net incomes flattening while the number of shares went up but, more importantly this does not indicate any value variations that could be attributed to IFRS adoption. Prices also changed by declining from 64.14 to 38.52 . This could be due to economic factors such as the fact that at the time of the post adoption period, the economy was on the down turn. The Book Value of Equity per Share (BVEPS) changed very little from 0.174 to 0.179 . This can be explained by the fact that the number of shares went up because of new issues and rights granted (Appendix8) while the book values did not change much. The Net Income Per Share (NIPS) declined from 7.255 to 3.014 which imply that income declined while the number of shares went up.

The control variables indicate a decline in the pre to post adoption period other than DISSUE (annual percentage change in total liabilities) and natural logarithm of market value of equity (LEV). Liabilities represented by SIZE (end year total liabilities divided by end year book 


\section{Mll Macrothink}

International Journal of Accounting and Financial Reporting ISSN 2162-3082 2011, Vol. 1, No. 1

value of equity) declined from 12.346 to 11.966 which could have arisen from the shortage of credit in the economy or the application of IFRS. Growth which is the annual percentage change in sales also declined. This could have been as a result of either the economy or the implementation of IFRS. The EISSUE (annual percentage change in shares) declined from 0.633 to 0.066 and DISSUE declined from 0.838 to 0.202 . This could either be due to economic factors or as a result of IFRS implementation. If it is due to the latter, then the changes could reflect the consequences of the new standards' stringent measures for liabilities inclusive of accruals. TURN (sales divided by end of year total assets) declined from 0.919 to 0.790 mainly due to declining sales while SIZE improved slightly.

The descriptive statistics report with all the variables not controlled send mixed signals as to whether accounting quality improved as a result of IFRS adoption or not. Only four of the indicators suggest that quality could have improved. Nevertheless, given that the variables are uncontrolled, more refined results are contained in the next section.

\section{Findings and Discussion of Results}

\subsection{Results from quantitative Research}

As reported in Table 5, the results are mixed as they indicate that listed companies applying IFRS show less evidence of earnings managements, more timely loss recognition and more value relevance of accounting amounts than firms that did not apply IFRS.

\section{INSERT TABLE 5 HERE}

The variability in earnings metrics improved from 0.1163 to 0.1358 which suggests that there was higher variability in earnings in the post adoption period. The use of this metric is based on the fact that less managed earnings show higher variability as opposed to managed earnings where there is a tendency to portray regular predetermined numbers. The arguments extend into IFRS reporting where it is argued that because of their ability to minimize managerial discretion, earnings reported under this regime tend to have higher variability as opposed to earnings reported under non IFRS. On this basis, one can say that accounting quality marginally improved. The second and third metrics are not consistent with the first one as they show that variability of change in NI over change in cash flow declined from 0.39649 to 0.20303 while correlation of accruals to cash flows declined from -0.770050 to -0.68220 both of which suggest that IFRS firms smooth earnings more than NIFRS firms. Although the finding is only marginal at $5 \%$ significant level, the implication is that accounting quality declined in the post adoption period.

The SPOS coefficient of -0.08637 is negative and insignificantly different from zero which indicates a lower occurrence of small positive earnings in the post adoption period. According to Bath et al. (2007:25), a negative coefficient when comparing IAS firms in the post and pre adoption period indicate that IAS firms manage earnings toward small positive amounts more frequently in the pre adoption period than they do in the post adoption period. The negative coefficient indicate low occurrence of small positive earnings under IFRS. This finding is 


\section{MInstitute Macrothink $^{m}$}

International Journal of Accounting and Financial Reporting ISSN 2162-3082 2011, Vol. 1, No. 1

therefore, consistent with the prediction that earnings are managed more in the pre adoption period.

Timely loss recognition is the measure for prevalence of large negative earnings where large negative results suggest that the loss recognition is not timely in the post adoption period. The timely loss recognition coefficient LNEG of -0.16548 is negative at 95\% confidence. According to Barth et al. (2007: 26) a positive coefficient on LNEG means that IAS firms recognize large losses more frequently in the post adoption period than they do in the pre adoption period. This finding is therefore, inconsistent with the prediction thus, implying that IFRS adoption did not result in accounting quality improvements.

The regression of price on net income and equity book value for IAS and (none) NIAS firms reveal that Adjusted $\mathrm{R}^{2}$ for IAS firms is insignificantly smaller than that of NIAS firms' i.e. $11.8 \%$ vs. $10.2 \%$. This finding is inconsistent with prediction as it indicates low value relevance as evidenced by price regressions in the post adoption period implying that accounting quality did not improve as a result of IFRS adoption. The regression statistics for good news is also inconsistent with prediction as it suggests that the value relevance decreased from $6.8 \%$ to below $0 \%$. The bad news metric insignificantly improved from $3.8 \%$ to $4.7 \%$ which implies that the value relevance of accounting amounts improved slightly after IFRS adoption. An overall assessment of the three value relevant measures gives mixed results as two of them insignificantly show no value relevance while one (bad news) indicate insignificant value relevance.

Three out of the eight measures were in line with the prediction that IFRS adoption results improved quality although sometimes with low or insignificant measures. These findings may suggest that the quality of accounting may have remained the same in the pre and post adoption periods. According to Barth et al. (2007: 35), in spite of similar controls for the accounting quality, the result from the interaction of features of the financial reporting system inclusive of accounting standards, their interpretation, enforcement and litigation differ. Barth et al. (2007: 35) continue to explain that in spite of efforts to mitigate effects of incentives and the economic environment, it is difficult to be absolutely sure that the findings are attributable to the change in the financial reporting system rather than the changes in firms' incentives and the economic environment.

In prior research, concerns were also raised that the inclusion of companies from the financial services sector could cause distortion in the results due to special regulations under bank supervision. In spite of these concerns, previous studies have indicated that no significant changes have been noted in studies that included firms from the financial sector. For instance, in the case of a Swedish study, Paananen (2009:14) tested for this situation by carrying out two different tests. One combined the data from firms in the financial sector and the other excluded them. In her final analysis, Paananen concluded that no qualitative differences were noted. In a case study on the impact of IFRS adoption in Egypt, a similar approach was adopted to address similar concerns. The findings concluded that inclusion of financial services did not have any specific impact. Chen et al. (2010:273) in a 15 country study of the EU concluded in their robustness tests that results are quantitatively unchanged after 
excluding the financial institution. On the basis of these three findings, data from financial services were included in the study as their inclusion may not have had any impact on the results.

The other question was whether the analysis of data from serious and non serious adopters could have an impact on the results. Paananen M. (2008:14) in the Swedish study separated serious adopters from the less committed ones and her findings were shocking. The quality of accounting worsened with the serious adopters. In the Kenyan study, listed companies are expected to vigorously follow IFRS and such a test was not considered relevant since the institutional framework around the listed companies are almost the same.

\subsection{Discussions -Reasons for Mixed findings and Contribution}

Some of the reasons why the findings on the impact of IFRS adoption on accounting quality are not in line with the predictions relates to non compliance as discussed above. The key reason being that the growing complexity of IFRS, that is the move towards fair value model, conflicts with regulators guidelines and legislation such as IFRS 4 (insurance contracts) (UNCTAD 2005:14). This reason has also been supported by the annual FiRe Awards (Chapter 1 introduction) which have consistently highlighted the fact that Kenyan companies have not achieved full compliance and disclosure is still very low. For example, the financial services sector which has some of the top listed companies, such as banks and insurance companies, usually have very low scores in the Fire Awards. In 2005, no company in this sector had a score of $80 \%$ and above even though 10 of them scored $60-79 \%$. This situation worsened in 2009 with fewer companies in the financial services sector scoring above $80 \%$.

Kenya and the EU have experienced similar problems in relation to IAS 39, on measurement and disclosure of financial instruments, where the complexities in the requirements have been a nightmare. The EU was opposed to IAS 39 because its application would result in volatility in their balance sheets and earnings which would ultimately affect the perceptions of investors and regulators of stability of various institutions (Soderstrom et al. 2007: 689). In Kenya, the fair valuations of financial instrument including bonds and derivatives have been hampered by lack of reliable market information as this sector is still at its infancy stages. Determination of fair value has thus, been very difficult and a times impossible. With this kind of non compliance, it would be difficult to measure out quality in the pre and post adoption periods accurately.

Another finding that came to the fore was the fact that Kenyan Accounting Standards (KAS) were previously modeled alongside IAS. Actually, the institute (ICPAK) changed a few wordings of the IAS and then named the standards as KAS. According to UNCATD (2005: 7), at the time Kenya was adopting IAS in 1999, there were 18 KAS while IAS had 39 standards. Of the $18 \mathrm{KAS}, 6$ had no material differences with corresponding IAS, while others had a few differences. About 20 of the IAS had no corresponding or equivalent Kenyan standard. This situation could therefore, have led to the narrowing of the quality of Accounting in the pre and post adoption period. This scenario is completely different from that of the EU where according to Soderstrom et al. (2007: 677), Europe historically had legal systems and combined with other political and economic differences created a vast diversity of accounting 


\section{MInstitute Macrothink $_{\text {Int }}$}

International Journal of Accounting and Financial Reporting ISSN 2162-3082 2011, Vol. 1, No. 1

systems. It is the recognition of this extreme diversity that motivated policy makers in the EU to consistently and systematically advocate for the harmonization of accounting standards. This explains why the impact of quality in the EU is felt more as their starting base was too far away from IFRS. This experience is also supported by Daske et al. (2008) arguments on code law and common Law countries. Because common law countries systems are already investor oriented, the adoption of IFRS may not exhibit high quality gains because they will already be investor oriented. Similar arguments have been extended by Prather et al. (2008) and Daske et al. (2007). Kenya is a common law country therefore, investor orientation existed and IFRS adoption has not created a new impetus. The finding is therefore, in line with Leuz, Nanda and Wysocki (2003) where they concluded that earnings smoothing are less pronounced in common law countries because conceptually, the IAS framework is similar to that found in common law countries. The Kenyan findings for earnings smoothing are actually insignificant in both periods.

Accounting Literature has also argued that voluntary adoption results in better increase in accounting quality as opposed to mandatory adoption as firms will voluntarily disclose more than the minimum amount of information required. Paananen et al. (2007:26) reported that earnings and book value became less value relevant during the IFRS mandatory period compared to both the IAS and IFRS voluntary periods. The Kenyan case can be described as voluntary adoption because there is no direct parliamentary act that has indicated that IFRS has to be followed. There are however, regulatory requirements like the Central Bank Act and the Insurance Regulators Act that require IFRS to be followed. In the findings, it is difficult to conclude whether there is impact of voluntary adoption since quality has not changed much.

Barth et al. (2007:2) also argue that accounting quality could increase based on rigorous enforcement. This matter is also raised in several literatures because it has also turned out that adopters can be classified as either serious adopters or label adopters. Daske et al. (2007) argued that firms have considerable discretion on how they adopt IFRS leading to serious and label adopters a view held by Prather et al. (2008). It can therefore, be argued that some Kenyan listed companies may fall into the category of label adopters thus, leading to an insignificant increase in accounting quality in the pre to post adoption era.

Mixed results regarding IFRS adoption could also be related to methodological issues foremost, being sample selection (Soderstrom 2007:686). A lot of prior research may have been based on voluntary adoption and hypothesized economic consequences and this bias may lead to an automatic conclusion that IFRS adoption leads to improved accounting quality. Soderstrom (2007:691) also argues that Firms already closer to IFRS may be willing to adopt due to lower costs and thus, have better quality. Another Methodology issue relates to omitted variables. It has been found that pricing mechanisms and analysis information and non disclosure of non financial information differ across firms and this may distort the findings. In the Kenyan study, this problem was solved by using similar firms for the two different standards thus; Kenyan findings could be much more accurate

Saunder, S.(2009:106) argue that in spite of IFRS adoption and spread earnings quality across IFRS countries might relate to variance in enforcement and this study lends credence 


\section{$\Lambda$ Macrothink}

to this idea.

\subsection{Contribution}

The key objective of the study was to asses if IFRS adoption has impacted on the quality of Accounting of Kenyan listed companies and this in turn would be a great contribution given that extant literature has questioned the vetting and significance of investing in IFRS. The study improved on various test conditions as reported in the introduction and the contributions include:

a. In terms of vetting of IFRS, the study reports from the eight objectives that scientifically tested for proof of evidence in quality increases as a result of IFRS adoption that quality improvement have not been noticeable despite the improved test conditions. The study contributed additional evidence that earnings management, timely loss recognition and value relevance does not improve because of IFRS, all factors being equal. Previous studies suggested further research in this area under better conditions. The quest for vetting of IFRS has also been raised by Johnson and Leone (2009) and Sunder (2009:106) where they argued that IFRS is not a silver bullet and shareholders have questioned the wisdom of investing in such a system

a. From qualitative study that looked critically at the structure of the Accounting profession in Kenya, it was apparent there are weak links in the organization of the profession, industry regulators, registrar of companies in Kenya (Custodian of the Company's act), the Constitution and the International Standard Setters. By improving on these linkages, this study believes better quality; measures can be derived from the Kenyan study.

b. This study also contributes to methodology by being the first study in Africa to extend earnings quality with matched samples in an environment where data and other control measures are scarce and where the world seems to pay a little attention. It is also the first study of its kind to be set up in a single stock exchange thus eliminating the need to average stock prices that come from several exchanges in a single economy. The methodology effectively ensured a common economic and political environment -two factors that are confounding and that needs to address for results to be credible. It is appreciated Nairobi stock exchange is small with only 54 companies but the findings under such the test conditions are realizable. Even if the test conditions are improved, it appears the promised benefits are unlikely to be realized.

c. The study also expands literature contribution by giving additional perspectives to the international accounting standards regarding the financial statement and market impact of adoption of these standards. This essentially leaves the role of IFRS to be that of a common reporting language around the world and not necessarily one of quality. 


\section{Macrothink \\ International Journal of Accounting and Financial Reporting \\ ISSN 2162-3082 \\ 2011, Vol. 1, No. 1}

\section{Conclusions and Recommendations}

This study has reviewed the impact of IFRS adoption on the accounting quality of listed companies in Kenya between 1995 and 2004. The study used a quantitative approach and document analysis. Based on prior literature, the accounting quality metrics applied were earnings management (four metrics), timely loss recognition (1 metric) and value relevance ( 3 metrics). The findings were mixed with three out of the eight metrics of the quantitative results indicating that quality has marginally improved while the other 5 out of eight indicated that quality declined marginally thus, leading to the conclusion that accounting quality has remained almost the same.

These findings are not different from the results from other studies, in other parts of the world, such as Germany by Paananen and Lin (2008:26), Clarkson et al. (2009:26), Houque et al. (2010:22) and many others where they all reported that IFRS adoption does not necessarily lead to improved quality in financial reporting. Paananen. (2008:17) in a similar study in Sweden stated that IFRS adoption did not improve the quality of accounting in Sweden and went on to advise that it is dangerous to draw conclusions on using this kind of measures. These results should therefore be seen as part of the evidence vetting IFRS. Notwithstanding the mixed outcome, these results can also be used to explain that accounting quality can improve from IFRS adoption rather than changes in managerial incentives. Soderstom and Sun (2007:695) are cautionary and state that one cannot compare their conclusions of studies in settings where adoption is mandatory, like Kenya, to studies where adoption is voluntary or optional. They argue that accounting quality after IFRS adoption hinges on several factors such as the quality of the standards, a country's legal and political system and financial reporting incentives (financial market development, capital structure, ownership and tax system). A review of this in the Kenyan context indicated some flaws in the economic environment that hindered the success of IFRS adoption. Chen et al. (2010:272) also argue IFRS adoption would not generate accounting information with same quality across countries as other factors would affect accounting quality. In summary, the findings are in line with many other findings where quality improvements are not conspicuous in a common law country whose domestic standards were a replica of international standards. Moreover, the fact that full compliance was not followed, in many cases, contributed to the conclusion that IFRS adoption has not significantly contributed to improvements in the quality of accounting but if all IFRS conditions were complied with then quality would improve. Broad interpretation of these results are discouraged because data collected from audited accounts generally represent what the auditors believe as the correct application of standards even if the application was compromised.

It is recommended that top management, external auditors and regulators being the key players in standards, need to work together and tighten compliance so that impact of IFRS could be felt more. Further research could be carried out on the period 2005 to 2010 to see how quality has progressed in these periods. Paananen and Sun (2007) extended their studies from a baseline study to subsequent periods and their findings reported a decline in quality and a similar study can also be extended in Kenya. 
The study focused on Kenyan listed companies, mainly because clear records are available from the stock exchange. The other areas which include public limited companies, cooperative societies, private companies and other companies which do not fall under regulators or stock listing could be studied. Such a study could lead to a better conclusion on the status of the impact of IFRS adoption on the quality of accounting in Kenya and not just listed companies. Another interesting area for study could be the reasons for the insignificant effect of IFRS adoption given the world wide belief that IFRS improves accounting quality. Such a study could shed light on where the adoptions are not going on well and would therefore form the back bone of improving quality of accounting.

\section{Acknowledgement}

Helpful comments and suggestions from Salvador Carmona (Editor) and other referees are very much appreciated. Material and all forms of assistance received from Institute of Certified Public Accountants of Kenya (ICPAK), USIU and the University of South Africa Graduate School of leadership are equally appreciated and indeed Doreen Alusa on her vigilance that the work be completed.

\section{Notes}

1. The term IFRS is used in this study to refer to both IFRS issued by IASB and IAS issued by IASC

\section{Bibliography}

ACCA (2008)Corporate Reporting P2 International; Berkshire, Kaplan Publishing UK

Accountant (2008) 'ICPAK Celebrating 30 years of Accounting Excellence' Journalof the Institute of Certified Public Accountants of Kenya pp 32-36.

Ashbaugh,H. and Pincus, M. (2001) 'Domestic Accounting Standards, International Accounting Standards and Predictability of Earnings', Journal of Accounting Research 39 (3) pp.417-434

Athianos, S., Vazakidis, A. andNikolaos, D. (2005) 'Financial Statement Effects of Adopting International Accounting Standards: The Case of Greece'. Available at SSRN: http://ssrn.com/abstract $=1829348$

Ball, R., Robin, A. and Wu, J. (2003) ' Incentives versus Standards: Properties of Accounting Income in 
four Asian Countries'. Journal of Accounting and Economics 29 : 1-51.

Barth, M. (2008)'Global Financial Reporting: Implications for US Academics'. The Accounting Review. 83(5): 1159-1179

Barth, M., Landsman, W. and Lang, M. (2007) 'International Accounting Standards and Accounting Quality'.Research paper Series, Stanford Graduate School of Business. http://ssrn.com/abstract=1029382

Barth, M., Landsman, W. and Lang, M. (2007) 'International Accounting Standards and Accounting Quality'Journal of Accounting Research 46:467-728

Bartov, E.Goldberg, S. and Kim M. (2005) Comparative Value Relevance among German, US And International Accounting Standards: A German stock Market perspective.Journal of Accounting,Auditing and Finance 20: 95-119

Chen H.,Tang Q., Jiang Y. and Lin Z.(2010) 'The Role of International Financial Reporting Standards in Accounting Quality:Evidence from the European Union'. Journal of International Financial Management and Accounting 21:3 2010. 220-278

Christensen H., Lee E., and Walker M., (2008) 'Incentives or Standards: What Determines Accounting Quality changes around IFRS Adoption?'Presented at the annual meeting of theAmerican Accounting Association in Anaheim California 3-6 Aug 2008.America Accounting Association. Available at SSRN:http://ssrn.com/abstract=1013054

Clarkson, P., Hanna J., Richardson, G. and Thompson, R. (2010) 'The Impact of IFRS Adoption on The Value Relevance of Book Value and Earnings' Available at SSRN:http://ssrn.com/abstract=1614362

Daske, H., Hail, L, Leuz, C., Verdi, R., (2008) 'Adopting a Label: Heterogeneity in the Economic Consequences of IFRS Adoptions'Presented at the annual meeting of the American Accounting Association, Anaheim California 3-6 Aug 2008.

America Accounting Association

Daske, H. and Gephardt, G. (2006)'International Financial Reporting Standards and Experts Perceptions of Disclosure Quality'.The University of Sydney ABACUS. 42: 3-4.

Elbannan, M., (2011) "Accounting and Stock Market Effects of International Accounting Standards Adoption in an Emerging Economy" Journal of Review of Quantitative Finance and Accounting Vol 1 36: pp 207-245

Hung, M. andSubramanyam, K. (2007) 'Financial Statement Effects of Adopting International Accounting 
Standards: the Case of Germany'. Review of Accounting Studies, Forthcoming. Available at SSRN: http://ssrn.com/abstract=622921

IAS Plus.,(2010)http://www.iasplus.com/standards/standards.html accessed on 1 Feb 2010

ICPAK,( 2008)-The Fire Award 2008

Houque, M., Dunstan, K., Karim, W. and Zijl, T. (2010) 'The Effect of IFRS Adoption and Investor Protection on Earnings Quality Around the World' Presented at Finance and Corporate Governance Conference 2010 at La Trobe University Australia in 2010

Hung, M. and Subramanyam, K (2007) 'Financial Statement Effects of Adopting International Accounting Standards: the case of Germany', Review of Accounting studies 12 (4) pp 623-657

Imhoff E., (2003) 'Accounting Quality, Auditing and Corporate Governance'Accounting Horizons: Special Issue on Accounting Quality, Supplement 2003, and pp. 117-128.

Johnson. S, Leone, M. (2009) 'CFO's on IFRS: Forget about It'

http://www.cfo.com/article.cfm/13517383?f=home_featured accessed on 24 April 2009

Lang M., Raedy J, and Yetman M (2003)'How Representative are Firms that are Cross Listed In the United States?An analysis of Accounting Quality'.Journal of Accounting Research 41: 363-386

Leuz, C. Nanda, D. and Wysocki, P. (2003) 'Earnings Management and Investor Protection: An International Comparison’ Journal of Financial Economics 69: 505-527

Paananen, M. and Lin, C.(2007)'The Development of Accounting Quality of IAS and IFRS Over Time: The Case of Germany'.Available at SSRN: http://ssrn.com/abstract=1066604

Singh, R. and Newberry, S. (2008) 'Corporate Governance and International FinancialReporting Standard (IFRS): The Case of DevelopingCountries'. Research in Accounting in Emerging Economies, Volume 8, 483-518

Athianos, S., Vazakidis, A. andNikolaos, D. (2005) 'Financial Statement Effects of Adopting International Accounting Standards: The Case of Greece' Available at SSRN: http://ssrn.com/abstract $=1829348$

Sunder, S. (2009) 'IFRS and the Accounting Consensus'Accounting Horizons 23(1):101-111

Soderstrom, N. and Sun, K. (2007), 'IFRS Adoption and Accounting quality: A review', European Accounting Review 16:4, 675-702 
Standardsforum (2009) http://www.estandardsforum.org/kenya/standard accessed on 8 March 2010

Tendeloo, B. and Vanstraelen, A. (2005) 'Earnings Management under German GAAP versus IFRS'. European Accounting Review 14: 155-180

World Bank (2010) Report on the observance of Standards and Codes (ROSC) on Kenya Accounting and Auditing Standards

UNDP (2010) Human $\quad$ Development Index http://hdr.undp.org/en/media/HDR_2010_EN_Tables_reprint.pdf accessed on 8/7/2011

UNCTAD (2006) Review of Practical Implementation issues of International Financial Reporting Standards- case study in Kenya

Table 1: Census selection Process

\begin{tabular}{|l|l|l|l|l|}
\hline & & Pre adoption & Post adoption & Total \\
\hline & From Nairobi Stock Exchange & 179 & 179 & 348 \\
\hline & Omitted due to missing data & $(19)$ & $(19)$ & $(19)$ \\
\hline & Total Sample & 160 & 160 & 320 \\
\hline
\end{tabular}

Table 2: Descriptive Statistics relating to application of IFRS-Industry Breakdown

\begin{tabular}{|l|l|l|l|l|}
\hline & $\begin{array}{l}\text { No of Firm Year } \\
\text { observations }\end{array}$ & $\begin{array}{l}\text { \% of firm year } \\
\text { observations }\end{array}$ & Firms of IAS & $\begin{array}{l}\text { No of IAS } \\
\text { Firms }\end{array}$ \\
\hline Manufacturing, Industrial \& Allied & 126 & 39.4 & 14 & 50 \\
\hline Financial services & 110 & 34.4 & 12 & 50 \\
\hline Agricultural sector & 34 & 10.6 & 4 & 50 \\
\hline Commercial Services & 50 & 15.6 & 6 & 50 \\
\hline Total & 320 & 100 & 36 & \\
\hline
\end{tabular}


Table 3: Descriptive Statistics relating to application of IFRS Year Breakdown

\begin{tabular}{|c|c|c|c|c|c|c|}
\hline & $\begin{array}{l}\text { No of Firm Year } \\
\text { observations }\end{array}$ & $\begin{array}{l}\% \text { of firm year } \\
\text { observations }\end{array}$ & $\begin{array}{l}\text { No of IAS } \\
\text { Firms }\end{array}$ & $\begin{array}{l}\% \text { of IAS } \\
\text { Firms }\end{array}$ & $\begin{array}{l}\text { No of NIAS } \\
\text { Firms }\end{array}$ & $\begin{array}{l}\% \text { of NIAS } \\
\text { Firms }\end{array}$ \\
\hline 1995 & 28 & 8.75 & & & 28 & 100 \\
\hline 1996 & 28 & 8.75 & & & 28 & 100 \\
\hline 1997 & 32 & 10.00 & & & 32 & 100 \\
\hline 1998 & 35 & 10.94 & & & 35 & 100 \\
\hline 1999 & 37 & 11.60 & & & 37 & 100 \\
\hline 2000 & 35 & 10.90 & 35 & 100 & & \\
\hline 2001 & 36 & 11.25 & 36 & 100 & & \\
\hline 2002 & 33 & 10.31 & 33 & 100 & & \\
\hline 2003 & 28 & 8.75 & 28 & 100 & & \\
\hline 2004 & 28 & 8.75 & 28 & 100 & & \\
\hline Total & 320 & 100.00 & 160 & & 160 & \\
\hline
\end{tabular}

Sample of firms that adopted IFRS between 1995 and 2004

1995-1999- Firms were expected to apply Kenya Accounting Standards (KAS) (Domestic standards) 2000 onwards-firms were expected to apply IFRS (Global Financial reporting standards)

Table 4:Descriptive Statistics relating to variables used in analyses

IFRS

$(\mathrm{N}=160)$

NIFRS(N=160)

\begin{tabular}{|l|l|l|l|l|l|l|l|l|l|}
\hline Test & Mean & Median & $\begin{array}{l}\text { Standard } \\
\text { Deviation }\end{array}$ & Skewness & Mean & Median & $\begin{array}{l}\text { Standard } \\
\text { Deviation }\end{array}$ & Skewness \\
\hline$\Delta \mathrm{NI}$ & 0.010 & 0.000 & 0.056 & 1.375 & -0.019 & 0.000 & 0.144 & -5.850 \\
\hline$\Delta \mathrm{CF}$ & -0.010 & 0.000 & 0.127 & -2.988 & 0.005 & -0.010 & 0.217 & 3.204 \\
\hline ACC & -0.031 & -0.020 & 0.105 & -2.274 & -0.035 & -0.030 & 0.083 & 0.177 \\
\hline CF & 0.068 & 0.050 & 0.127 & 3.241 & 0.098 & 0.080 & 0.114 & 0.870 \\
\hline
\end{tabular}




\begin{tabular}{|l|l|l|l|l|l|l|l|l|l|}
\hline SPOS & 0.081 & 0.000 & 0.273 & 3.078 & & 0.082 & 0.000 & 0.275 & 3.053 \\
\hline LNEG & 0.081 & 0.000 & 0.273 & 3.078 & & 0.082 & 0.000 & 0.0275 & 3.053 \\
\hline RETURN & 0.011 & 0.010 & 0.157 & -2.674 & & 0.001 & 0.000 & 0.120 & -6.623 \\
\hline NI/P & 0.060 & 0.100 & 0.487 & -5.686 & & 0.126 & 0.090 & 0.417 & 3.713 \\
\hline P & 38.521 & 19.800 & 45.200 & 2.908 & 64.146 & 49.000 & 54.023 & 1.506 \\
\hline BVEPS & 0.179 & 0.200 & 0.047 & -1.460 & 0.174 & 0.200 & 0.054 & -1.410 \\
\hline NIPS & 3.014 & 2.570 & 9.477 & 0.210 & 7.255 & 3.650 & 12.757 & 3.135 \\
\hline
\end{tabular}

Control Variables

\begin{tabular}{|l|l|l|l|l|l|l|l|l|l|}
\hline LEV & 11.966 & 5.700 & 12.716 & 1.345 & 12.346 & 6.390 & 14.747 & 1.960 \\
\hline GROWTH & 1.268 & 1.040 & 1.542 & 8.211 & 1.630 & 1.060 & 3.522 & 6.138 \\
\hline EISSUE & 0.066 & 0.000 & 0.344 & 7.377 & 0.633 & 0.000 & 3.269 & 7.546 \\
\hline DISSUE & 0.202 & 0.050 & 0.610 & 2.965 & 0.838 & 0.060 & 5.167 & 9.992 \\
\hline TURN & 0.790 & 0.680 & 0.765 & 2.090 & 0.919 & 0.600 & 0.974 & 2.684 \\
\hline SIZE & 21.053 & 20.840 & 1.587 & 0.210 & 20.976 & 21.130 & 1.680 & -1.080 \\
\hline CF & 0.068 & 0.050 & 0.127 & 3.241 & & 0.098 & 0.080 & 0.114 & 0.870 \\
\hline
\end{tabular}

$\Delta$ NI-Change in annual earningsbased on end of year total assets)

$\Delta$ CF-change in annual net cashflow (based on end of year total assets)

ACC-earnings less cash flow from operating activities scaled by end of year total assets

SPOS-is an indicator $=1$ for observations with annual earnings scaled by total assets between 0.00 and 0.01

LNEG-is an indicator that equals 1 for observations with annual earnings scaled by total assets less than $-0.20$

RETURN-annual stock return from 9 months prior to 3 months after the firms fiscal year end

P-Price as of 6 months after fiscal year end

NI/P-earnings per share divided by beginning of year prices

BVEPS-Book value of equity per share

NIPS-Net income per share

LEV-end year total liabilities divided by end year book value of equity 
GROWTH-Annual \% of change in sales

EISSUE-annual \% change in common stock

DISSUE-annual \% change in total liabilities

TURN-Sales divided by end of year total assets

SIZE-is the natural logarithm of market value of equity in millions of shillings as of year end

NUMEX-Number of exchange listings

AUD-an indicator that equals 1 if the auditor is one of the large international accounting firms

XLIST-an indicator that equals 1 if the firm is listed on any US stock exchange and worldscope

CLOSE-\% of closely held shares

Table 5: Comparison of Pre adoption and post adoption accounting quality

Earnings Management

\begin{tabular}{|l|l|l|l|l|}
\hline Measure & Prediction & Post $(\mathrm{N}=160)$ & & Pre(N=160) \\
\hline Variability of $\Delta \mathrm{NI}^{*}$ & Post>Pre & 0.01358 & 0.01163 \\
\hline Variability of $\Delta \mathrm{NI}^{*}$ over $\Delta \mathrm{CF}^{*}$ & Post>Pre & 0.20303 & 0.39649 \\
\hline Correlation of ACC* and $\mathrm{CF}^{*}$ & Post $>$ Pre & -0.68220 & & -0.77050 \\
\hline Small Positive NI (SPOS) & Post $>$ Pre & & -0.08637 & \\
\hline
\end{tabular}

Timely loss Recognition

\begin{tabular}{|l|l|l|l|l|}
\hline Measure & Post>Pre & & -0.61548 & \\
\hline Large Negative NI (LNEG) & Post>Pre & & & \\
\hline
\end{tabular}




\section{Value Relevance}

Regression Adjusted $\mathrm{R}^{2}$

\begin{tabular}{|l|l|l|l|l|}
\hline Measure & Prediction & Post $(\mathrm{N}=)$ & Pre(N=) \\
\hline Price & Post $>$ Pre & 0.10230 & 0.11880 \\
\hline Good News & Post $>$ Pre & -0.00700 & & 0.06860 \\
\hline Bad News & Post $>$ Pre & 0.04770 & & 0.03850 \\
\hline
\end{tabular}

*Significantly different between IFRS and NIFRS firms at the .05 level (one sided)

Variability of $\Delta \mathrm{NI}^{*}$ over $\Delta \mathrm{CF}^{*}$-variance of residuals from a regression of the $\Delta \mathrm{NI}(\Delta \mathrm{CF})$ on the control variable and the variability of $\Delta \mathrm{NI}^{*}$ over $\Delta \mathrm{CF}^{*}$ as the ratio of variability of $\Delta \mathrm{NI}^{*}$

Divided by the variability of Variability of $\Delta \mathrm{CF}^{*}$

Correlation of $\mathrm{ACC}^{*}$ and $\mathrm{CF}^{*}$ is the partial spearman correlation between the residuals from $\mathrm{ACC}$ and $\mathrm{CF}$ regressions

Table 6: Time Series Data for Market Indicators

\begin{tabular}{|l|l|l|l|l|l|l|l|}
\hline $\begin{array}{l}\text { Key Market } \\
\text { Investors }\end{array}$ & $\mathbf{1 9 9 1}$ & $\mathbf{1 9 9 2}$ & $\mathbf{1 9 9 3}$ & $\mathbf{1 9 9 4}$ & $\mathbf{1 9 9 5}$ & $\mathbf{1 9 9 6}$ & $\mathbf{1 9 9 7}$ \\
\hline N.S.E Index & 958.29 & $1,167.29$ & $2,513.74$ & $4,559.40$ & $3,468.88$ & $3,114.11$ & $3,115.14$ \\
\hline $\begin{array}{l}\text { Market Capitalization } \\
\text { (Kshs Billion) }\end{array}$ & 12.71 & 23.06 & 72.39 & 136.83 & 112.86 & 99.95 & 114.31 \\
\hline $\begin{array}{l}\text { Shares Traded } \\
\text { (thousand) }\end{array}$ & 16,648 & 14,811 & 27,292 & 42,758 & 59,385 & 113,559 & 143,584 \\
\hline $\begin{array}{l}\text { Shares Outstanding } \\
\text { (million) }\end{array}$ & 668 & 745 & 891 & 1,585 & 1,801 & 2,531 & 2,965 \\
\hline $\begin{array}{l}\text { Turn Over Ratio } \\
\text { (shares)\% }\end{array}$ & 2.49 & 1.99 & 3.06 & 2.70 & 3.30 & 4.49 & 4.84 \\
\hline $\begin{array}{l}\text { Value of shares } \\
\text { Traded (million) }\end{array}$ & 302 & 385 & 824 & 3,076 & 3,345 & 3,962 & 6,149 \\
\hline $\begin{array}{l}\text { Number of } \\
\text { Transactions(sales) }\end{array}$ & 8.742 & 12.020 & 17,885 & 35,581 & 54,280 & 63,304 & 80,546 \\
\hline
\end{tabular}




\begin{tabular}{|l|l|l|l|l|l|l|l|}
\hline $\begin{array}{l}\text { Av. Value per } \\
\text { Transaction }\end{array}$ & $34,490.87$ & $31,994.38$ & $46,089.23$ & $77,717.99$ & $61,630.46$ & 62.6 & 76.3 \\
\hline
\end{tabular}

Table 7: Time Series Data for Market Indicators

\begin{tabular}{|c|c|c|c|c|c|c|c|}
\hline $\begin{array}{ll}\text { Key } & \text { Market } \\
\text { Indicators } & \\
\end{array}$ & 1998 & 1999 & 2000 & 2001 & 2002 & 2003 & 2004 \\
\hline N.S.E Index & $2,952.06$ & $2,303.18$ & $1,913.35$ & $1,355.05$ & $1,362.85$ & $2,737.59$ & $2,945.58$ \\
\hline $\begin{array}{l}\text { Market Capitalization } \\
\text { (Kshs Billions) }\end{array}$ & 129.02 & 106.74 & 101.42 & 86.1 & 112.59 & 317.89 & 306.02 \\
\hline $\begin{array}{ll}\text { Shares } & \text { Traded } \\
\text { (thousand) } & \end{array}$ & 111,511 & 157,487 & 141,648 & 109,191 & 148,836 & 381,230 & 625,328 \\
\hline $\begin{array}{l}\text { Shares outstanding } \\
\text { (millions) }\end{array}$ & 3.303 & 3,360 & 3,646 & 4,354 & 4,380 & 4,249 & 5,097 \\
\hline $\begin{array}{ll}\text { Turnover } & \text { ratio } \\
\text { (shares)\% } & \end{array}$ & 3.38 & 4.69 & 3.88 & 2.51 & 3.40 & 8.97 & 12.27 \\
\hline $\begin{array}{l}\text { Value of shares Traded } \\
\text { (millions) }\end{array}$ & 4,583 & 5,158 & 3,632 & 3,121 & 2,921 & 15,251 & 22,324 \\
\hline $\begin{array}{ll}\text { Number } & \text { of } \\
\text { transactions(Sales) }\end{array}$ & 54,925 & 45,887 & 32,906 & 28,225 & 25,051 & 91,889 & 124,793 \\
\hline $\begin{array}{lcl}\text { Av. Value } & \text { per } \\
\text { Transaction }(000) & \end{array}$ & 83.5 & 112.4 & 110.4 & 110.1 & 116.61 & 165.97 & 178.69 \\
\hline
\end{tabular}

